\title{
A study on health related risk factors and health seeking behavior among elderly population in rural Bangladesh
}

\author{
F Ferdaus ${ }^{1}$, R Zahan², *MA Rahman ${ }^{3}$, s Chowdhury ${ }^{4}$
}

\begin{abstract}
Globally, $10 \%$ of the world population is elderly people and it is expected to increase to $21 \%$ in the year 2051. In the year 2002, the number of elderly people in the world was estimated to be 605 million, which is expected to rise to more than 1.2 billion by the year 2025 . This crosssectional study was conducted to $\square$ nd out the health-related quality of life and risk factors among elderly population in the selected rural population of Shyamnagar Upazila of Satkhira District. Data was collected from both the male and female population, aged 60 years and above, during February to June 2018. Purposive sampling technique was used to collect data from 50 respondents by face to face interview with semi-structured questionnaire. In the study, the mean age of elderly was male $63( \pm 2.95)$ years, and female $61.8( \pm 2.04)$ years. Other socio-demographic factors among elderly were as follows: 20 (40\%) of elderly were illiterate, $15(30 \%)$ of elderly were doing business, 21 (42\%) were doing farming. 40 (80\%) of elderly were married. The study also reported the five most common disease co-morbidities for elderly which included: $71.43 \%$ male and $28.57 \%$ female had hypertension while $72.22 \%$ of male and $27.78 \%$ of female patients were already treated, $68.75 \%$ male and $31.25 \%$ female had diabetes mellitus and $100 \%$ of them were treated, $50 \%$ of male elderly and $50 \%$ of female elderly were suffering bone and joint pain/arthritis and $60 \%$ of them were received treatment, hearing impairment found among $100 \%$ of male while two-third of patients received treatment, one-third of female and two-third of male elderly suffered from poor vision; however, only one-third of female patients were treated. On the basis of these findings, it can be recommended that there is a need to develop geriatric health-care services.
\end{abstract}

Keywords: Bangladesh, Older persons, Quality of life.

1. Dr. Farhana Ferdaus, Assistant Professor and Head, Department of Community Medicine, Khulna City Medical College, Khulna.

2. Dr. Refat Zahan, Assistant Professor and Head, Department of Community Medicine, Ad-din Akij Medical College, Khulna.

3. Dr. Md. Abdur Rahman, Assistant Professor and Head, Department of Pharmacology \& Therapeutics, Ad-din Akij Medical College, Khulna. Email: dr.rana3939@gmail.com

4. Dr. Shahin Chowdhury. 
Introduction

Ageing is a global phenomenon. With tremendous improvement in global health, people live longer; however, it poses special challenges for the 21st century. In 2011, life expectancy in countries like Japan and Switzerland was already more than 82 years. ${ }^{1}$ Countries' health systems around the world are burdened with increasing health care expenditures for ageing populations. In Malaysia, a projected model estimated that the number of elderly would reach 3.4 million in 2020 , which is more than $10 \%$ of the population. ${ }^{2}$ The proportion of older persons in Bangladesh is significantly increasing due to demographic transition. This will bring new demands related to older persons' health and social needs. Expeditious development of initiatives to face these coming challenges is required. The majority of Bangladeshis (including older persons) live in rural areas. ${ }^{3}$ These areas are considered disadvantageous due to their lack of modern facilities for citizens. This lack may affect older persons' quality of life. A study of older persons in a northern district of Bangladesh 4 reported a low mean quality of life score. This study also reported that participants' sex, family type, and occupation influenced quality of life scores. However, these results may not be transferable to other regions of Bangladesh due to regional differences in older persons' physical status, level of education, and economic status. The present study, therefore, investigates older persons' quality of life and its relationship to various sociodemographic characteristics in two southern districts of Bangladesh. Older persons may suffer from various health and social problems.5,6 Their social problems may include inadequate financial support from the government, insufficient health care, weakening family care systems, ${ }^{7}$ and decreasing social interactions. All of these problems may contribute to reduced quality of life and even disability. Quality of life is "an individual's perception of their position in life in the context of the culture and value systems in which they live and in relation to their goals, expectations, standards and concerns". 8 It is important to investigate the lives of older persons and the problems that they face..

\section{Materials and methods}

This cross-sectional study was conducted to $\square$ nd out the health-related quality of life and risk factors among elderly population in the selected rural population of Shyamnagar Upazila of Satkhira District. Data was collected from both the male and female population, aged 60 years and above, during February to June 2018. Purposive sampling technique was used to collect data from 50 respondents by face to face interview with semi-structured questionnaire. No sensitive or privacy invasive questions were asked. They were interviewed after filling up the informed consent form. All the data were checked and edited after collection. Results were analyzed by using SPSS for Windows $\mathrm{XP}$ program version 17.0. An analysis plan was developed keeping in view with the objectives of the study. Appropriate statistical tests were done according to the need of the study objectives where and whenever required. 
Results:

Table 01: Socio-demographic characteristics of respondents

\begin{tabular}{|c|c|c|}
\hline Characteristics & Male (\%) $n=30$ & Female (\%) n= 20 \\
\hline $\begin{array}{l}\text { Age (in years) } \\
\qquad \begin{array}{r}60-62 \\
63-65 \\
66-68 \\
\square 69 \\
\end{array}\end{array}$ & $\begin{array}{c}12(40.00 \%) \\
8(26.67 \%) \\
8(26.67 \%) \\
2(6.67 \%) \\
\end{array}$ & $\begin{array}{c}10(50.00 \%) \\
8(40.00 \%) \\
2(10.00 \%) \\
00 \\
\end{array}$ \\
\hline $\begin{array}{c}\text { Marital Status } \\
\text { Married } \\
\text { Unmarried } \\
\text { Widowed }\end{array}$ & $\begin{array}{c}30(100.00 \%) \\
00 \\
00\end{array}$ & $\begin{array}{c}10(50.00 \%) \\
00 \\
10(50.00 \%)\end{array}$ \\
\hline Religion & $\begin{array}{c}28(93.33 \%) \\
2(6.67 \%) \\
0\end{array}$ & $\begin{array}{c}20(100.00 \%) \\
0 \\
0\end{array}$ \\
\hline $\begin{array}{l}\text { Educational Status } \\
\qquad \begin{array}{c}\text { Illiterate } \\
\text { Primary } \\
\text { Secondary } \\
\text { SSC } \\
\text { HSC and above }\end{array} \\
\end{array}$ & $\begin{array}{c}8(26.67 \%) \\
12(40.00 \%) \\
5(16.67 \%) \\
5(16.67 \%) \\
0\end{array}$ & $\begin{array}{c}12(60.00 \%) \\
5(25.00 \%) \\
3(15.00 \%) \\
0 \\
0\end{array}$ \\
\hline $\begin{array}{l}\text { Occupation } \\
\text { Business } \\
\text { Farming } \\
\text { Day labor } \\
\text { Shop keeper } \\
\text { Housewife }\end{array}$ & $\begin{array}{c}12(40.00 \%) \\
16(53.33 \%) \\
0 \\
2(6.67 \%) \\
0\end{array}$ & $\begin{array}{c}3(15.00 \%) \\
5(25.00 \%) \\
0 \\
0 \\
12(60.00 \%)\end{array}$ \\
\hline
\end{tabular}

In the study, the mean age of elderly was male $63( \pm 2.95)$ years, and female 61.8 $( \pm 2.04)$ years. Other socio-demographic factors among elderly were as follows: $20(40 \%)$ of elderly were illiterate, $15(30 \%)$ of elderly were doing business, 21 (42\%) were doing farming. $40(80 \%)$ of elderly were married

Table 02: Smoking habit (Current) of respondents

\begin{tabular}{|c|c|c|c|}
\hline \multirow{2}{*}{$\begin{array}{c}\text { Cigarette } \\
\text { Smoking }\end{array}$} & \multicolumn{2}{|c|}{ Respondents } & Total \\
\cline { 2 - 4 } & Male (\%) $\mathrm{n}=30$ & Female (\%) $\mathrm{n}=20$ & $14(28.00 \%)$ \\
\hline No & $12(85.71 \%)$ & $2(14.29 \%)$ & $36(72.00 \%)$ \\
\hline Total & $30(60.00 \%)$ & $18(50.00 \%)$ & $50(100.00 \%)$ \\
\hline Significance & $\square^{2}=5.357, \quad$ df $=1, \quad \square^{2} /$ df $=5.36, \quad \mathrm{P}\left(\square^{2}>5.357\right)=0.0206$ \\
\hline
\end{tabular}


The data revealed that majority $(28 \%)$ were currently smoker and rest $(72 \%)$ were currently tobacco nonsmoker. Among the current smokers, $(85.71 \%)$ were male and among nonsmokers majority (50\%) were female. Chi-square test showed signi $\square$ cant association between smoking habit and sex $(p=0.0206)$.

Table 03: Tobacco chewing habit among the respondents

\begin{tabular}{|c|c|c|c|}
\hline \multirow{2}{*}{$\begin{array}{c}\text { Tobacco } \\
\text { chewing habit }\end{array}$} & Male & Female & Total \\
\cline { 2 - 4 } & $10(40.00 \%)$ & $15(60.00 \%)$ & $25(50.00 \%)$ \\
\hline Yes & $20(80.00 \%)$ & $5(20.00 \%)$ & $25(50.00 \%)$ \\
\hline No & $30(60.00 \%)$ & $20(40.00 \%)$ & $50(100.00 \%)$ \\
\hline Total & ${ }^{2}=8.333, \quad$ df $=1$, & $\square^{2} /$ df $=8.33, \quad P\left(\square^{2}>8.333\right)=0.0039$ \\
\hline
\end{tabular}

Among the respondents, $25(50 \%)$ were tobacco non chewer. Only $25(50 \%)$ had the habit, among them majority were female
15 (60\%). Signi $\square$ cant association was found between sex and current tobacco chewing habit $(p=0.0039)$.

Table 04: Five commonest risk factors among respondents

\begin{tabular}{|c|c|c|c|}
\hline Risk Factors & Male (\%) $n=30$ & Female(\%) $n=20$ & Total(\%) $n=50$ \\
\hline Hypertension & & & \\
\hline Yes & $20(71.43 \%)$ & $8(28.57 \%)$ & $28(56.00 \%)$ \\
No & $10(45.46 \%)$ & $12(54.54 \%)$ & $22(44.00 \%)$ \\
\hline Diabetes Mellitus & & & \\
\hline Yes & $22(68.75 \%)$ & $10(31.25 \%)$ & $32(64.00 \%)$ \\
No & $8(44.44 \%)$ & $10(55.56 \%)$ & $18(36.00 \%)$ \\
\hline Joint Pain/Arthritis & & & $30(60.00 \%)$ \\
\hline Yes & $15(50.00 \%)$ & $15(50.00 \%)$ & $20(40.00 \%)$ \\
\hline No & $15(75.00 \%)$ & $5(25.00 \%)$ & \\
\hline Hearing Impairment & & & $5(10.00 \%)$ \\
\hline Yes & $5(100.00 \%)$ & $20(44.44 \%)$ & $45(90.00 \%)$ \\
\hline No & $25(55.56 \%)$ & & $19(38.00 \%)$ \\
\hline Vision impairment/ & & $6(31.58 \%)$ & $31(62.00 \%)$ \\
\hline Yaract & $13(68.42 \%)$ & $14(14.16 \%)$ & \\
No & $17(54.84 \%)$ & &
\end{tabular}


Table 05: Sub analysis among elderly receiving treatment for risk factors

\begin{tabular}{|c|c|c|c|}
\hline Treatment Received & Male (\%) & Female (\%) & Total (\%) \\
\hline Hypertension(n=28) & & & \\
\hline Yes & $13(72.22 \%)$ & $5(27.78 \%)$ & $18(64.29 \%)$ \\
No & $7(70.00 \%)$ & $3(30.00 \%)$ & $10(35.71 \%)$ \\
\hline Diabetes Mellitus(n=32) & & & $32(100.00 \%)$ \\
\hline Nes & $22(68.75 \%)$ & $10(31.25 \%)$ & 0 \\
\hline Joint Pain/Arthritis(n=30) & 0 & 0 & $18(60.00 \%)$ \\
\hline Yes & $10(55.56 \%)$ & $8(44.44 \%)$ & $12(40.00 \%)$ \\
No & $5(41.67 \%)$ & $7(58.33 \%)$ & $2(40.00 \%)$ \\
\hline Hearing Impairment (n=5) & & & $3(60.00 \%)$ \\
\hline Yes & $2(100.00 \%)$ & 0 & \\
No & $3(100.00 \%)$ & 0 & $12(63.16 \%)$ \\
\hline Visual & & & $7(36.84 \%)$ \\
\hline impairment/Cataract & & & \\
(n=19) & $8(33.33 \%)$ & \\
\hline Yes & $5(71.43 \%)$ & $2(28.57 \%)$ & \\
\hline No & &
\end{tabular}

The study also reported the five most common disease co-morbidities for elderly which included: i) $71.43 \%$ male and $28.57 \%$ female had hypertension while $72.22 \%$ of male and $27.78 \%$ of female patients were already treated; ii) $68.75 \%$ male and $31.25 \%$ female had diabetes mellitus and $100 \%$ of them were treated; iii) $50 \%$ of male elderly and $50 \%$ of female elderly were suffering from bone and joint pain/arthritis and $60 \%$ of them were received treatment; iv) hearing impairment found among $100 \%$ of male while two-third of patients received treatment; v) one-third of female and two-third of male elderly suffered poor vision; however, only one-third of female patients were treated.

\section{Discussion}

Understanding variation and relationships among socio-demographic factors are increasing epidemiological interest in studying the effects of contextual and geographical factors on health disparities. ${ }^{9}$ In our study the mean age of elderly was male $63( \pm 2.95)$ years, and female $61.8( \pm 2.04)$ years. Other socio-demographic factors among elderly were as follows: $20(40 \%)$ of elderly were illiterate. Generally, those with higher educational levels could have better awareness of health and be more involved in cognitive activities such as reading and writing. Moreover, illiteracy, significantly related to malnutrition and a further risk for a poor health state $^{10}$ could affect upon the health status of studied elderly. $15(30 \%)$ of elderly were doing business, 21 (42\%) were doing farming. $40(80 \%)$ of elderly were married.

Among 50 respondents (28\%) were currently smoker and rest (72\%) were currently tobacco nonsmoker. Among the current smokers, (85.71\%) were male and among nonsmokers majority (50\%) were female. Chi-square test showed signi $\square$ cant association between smoking habit and sex $(p=0.0206)$.

Among the respondents, $25(50 \%)$ were tobacco non chewer. Only 25 (50\%) had the habit, among them majority were female 15 (60\%). Signi $\square$ cant association was found 
between sex and current tobacco chewing habit $(p=0.0039)$.

The study also reported the five most common disease co-morbidities for elderly which included: i) $71.43 \%$ male and $28.57 \%$ female had hypertension while $72.22 \%$ of male and $27.78 \%$ of female patients were already treated; ii) $68.75 \%$ male and $31.25 \%$ female had diabetes mellitus and $100 \%$ of them were treated; iii) $50 \%$ of male elderly and $50 \%$ of female elderly were suffering bone and joint pain/arthritis and $60 \%$ of them were received treatment; iv) hearing impairment found among $100 \%$ of male while twothird of patients received treatment; v) onethird of female and two-third of male elderly suffered poor vision; however, only one-third of female patients were treated. These data are consistent with other studies conducted among older persons in India ${ }^{12,13}$ and the world. ${ }^{14,15}$ In this study, hypertension was registered as the second most common morbidity $(64.29 \%)$. Similar finding has been reported in a study among older persons in India ${ }^{11,16}$ and abroad. ${ }^{17,18}$ Cataract was present in $63.16 \%$ elderly subjects. Sharma et al.11 reported 30\%; Shankar et al., 20 48\%; and Shraddha et al., ${ }^{19} 30.2 \%$, from different rural parts of India.

\section{Conclusion}

The elevated morbidity load among elderly population pressurizes for efforts to assist them with specialized healthcare. The elderly population must be made aware of periodic medical checkups to enable prevention and early recognition of the chronic ailments. Furthermore, the study shows that elderly people living in rural areas are the most vulnerable group in their health-seeking behavior. To overcome this, the policymakers must concentrate more on rural elderly population and on their negative views, which stop them from seeking health care.

\section{Acknowledgement}

The authors gratefully acknowledge the technical support provided by Department of Community Medicine, Khulna City Medical College, Khulna.

Conflict of Interest: Nothing to declare.

\section{References}

1. World Health Organization. Global Health Observatory - Life expectancy: Life expectancy by country. http://apps.who.int/gho/data/ node. main.688?lang=en (accessed Dec 2015).

2. Mat R, Taha HM. Socio-economic characteristics of the elderly in Malaysia, 21st Population Census Conference, Kyoto Japan, 19-21 Nov, 2003.

3. M. M. Naing, S. Nanthamongkolchai, and C. Munsawaengsub, "Quality of life of the elderly people in Einme Township Irrawaddy Division, Myanmar," Asia Journal of Public Health. vol. 1, no. 2, pp. 4-10. December 2010.

4. D. Kamra, "A community based epidemiological study on quality of life among rural elderly population of Punjab," International Journal of Recent Trends in Science and Technology, vol. 11, no. 2, pp. 192-197, June 2014.

5. Y. Khaje-Bishak, L. Payahoo, B. Pourghasem, and M. A. Jafarabadi, "Assessing the quality of life in elderly people and related factors in Tabriz, Iran," Journal of Caring Sciences, vol. 3, No 4, pp. 257-263, December 2014.

6. D. V. Jeste et al., "Association between older age and more successful ageing: critical role of resilience and depression," American Journal of Psychiatry, vol. 170, no. 2, pp. 188-198, February 2013.

7. M. N. Islam and D. C. Nath, "A future journey to the elderly support in Bangladesh," 
Journal of Anthropology, vol. 2012, pp. 1-6, 2012.

8. World Health Organization Quality of Life Group, "Development of the World Health Organization WHOQOLBREF quality of life assessment," Psychological Medicine. vol. 28, no. 3, pp. 551-558, May 1998.

9. Cummins $S$, Curtis $S$, Diez-Roux AV, Macintyre S. Understanding and representing 'place' in health research: A relational approach. Social Sci Med 2007; 65(9):1825-38.

10. Cheng ST, Ngoh HJ, Harith S. Prevalence of malnutrition among institutionalized elderly people in Northern Peninsular Malaysia: Gender, ethnicity and agespecific). Sains Malaysiana 2012;41(1):141-8.

11. Sharma D, Mazta SR, Parashar A. Morbidity pattern and health seeking behaviour of aged population residing in Shimla hills of north India. J Fam Med Prim Care 2013;2(2):188-93.

12. Sunder L, Chadha SL, Bhatia PC. A study on senior citizens in rural areas health for the millions. Health Millions 1999; 25:1820.

13. Padda AS, Mohan V, Singh J, Deepti SS, Singh G, Dhillon HS, et al. Health profile of aged persons in urban and rural field practice areas of Medical College Amritsar. Indian J Community Med 1998;23:72-6.
14. Clausen F, Sandberg E, Ingstad B, Hjortdahl P. Morbidity and health care utilisation among elderly people in Mmankgodi village, Botswana. J Epidemiol Community Health 2000; 54:58-63

15. Cheng YH, Chi I, Boey KW, Ko LS, Chou $\mathrm{KL}$. Self-rated economic condition and the health of elderly persons in Hong Kong. Soc Sci Med 2002;55:1415-24.

16. Munshi $Y I$, lqbal $M$, Rafique $H$, Ahmad $Z$. Geriatric morbidity pattern and depression in relation to family support in aged population of Kashmir valley. Internet $\mathrm{J}$ Geriatr Gerontol 2008;4:14-6.

17. Graciani A, Banegas JR, López-García E, Rodríguez-Artalejo F. Prevalence of disability and associated social and health-related factors among the elderly in Spain: a population-based study. Maturitas 2004;48:381-92.

18. Kaplan MS, Huguet N, Feeny DH, McFarland $\mathrm{BH}$. Selfreported hypertension prevalence and income among older adults in Canada and the United States. Soc Sci Med 2010;70:844-9.

19. Shraddha K, Prashantha B, Prakash B. Study on morbidity pattern among elderly in an urban population of Mysore, Karnataka. Int J Med Biomed Res 2012;1(3):215-23.

20. Shankar R, Tandon J, Gambhir IS, Tripathi CB. Health status of elderly population in rural area of Varansi district. Indian $\mathrm{J}$ Public Health 2007;51(1):56-58 